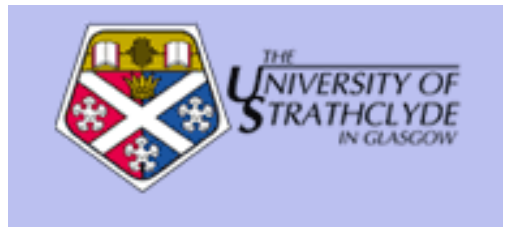

Ellis, Sue (2007) Policy and research: lessons from the Clackmannanshire synthetic phonics initiative. In: Approaching Difficulties in Literacy Development: Assessment, Pedagogy and Programmes. Sage, London, pp. 39-51.

http://strathprints.strath.ac.uk/20642/

Strathprints is designed to allow users to access the research output of the University of Strathclyde. Copyright (C) and Moral Rights for the papers on this site are retained by the individual authors and/or other copyright owners. You may not engage in further distribution of the material for any profitmaking activities or any commercial gain. You may freely distribute both the url (http://strathprints.strath.ac.uk) and the content of this paper for research or study, educational, or not-for-profit purposes without prior permission or charge. You may freely distribute the url (http://strathprints.strath.ac.uk) of the Strathprints website.

Any correspondence concerning this service should be sent to The Strathprints Administrator: eprints@cis.strath.ac.uk 
Status: Book chapter

\title{
Reference
}

Ellis, S (2009) 'Policy and Research: lessons from the Clackmannanshire synthetic phonics initiative' in F. Fletcher-Campbell, J. Soler and G. Reid (Eds) Approaching Difficulties in Literacy Development: Assessment, Pedagogy and Programmes London: Sage/Open University. P. 39-51

\section{Policy and research: Lessons from the Clackmannanshire Synthetic Phonics Initiative}

\section{SUE ELLIS University of Strathclyde, Scotland}

\begin{abstract}
This article explores why policy makers in England and Scotland responded so differently to the Clackmannanshire study on synthetic phonics. It suggests that a deeper understanding of the national and local policy contexts can explain Scotland's response. Analysis of the wider context of the Clackmannanshire initiative supports Moss and Huxford's (2007) argument that literacy problems cannot be couched within a single paradigm's field of reference, and that policy makers need to consider evidence from different paradigms if they are to make robust decisions.
\end{abstract}

Keywords Clackmannanshire; curriculum policy; early intervention; literacy; staff development; synthetic phonics

The Synthetic Phonics experiment in Clackmannanshire, Scotland has, it seems, had a significant impact on literacy policy in England. The Westminster Select Committee Enquiry into Teaching Children to Read concluded, 'In view of the evidence from the Clackmannanshire study . . . we recommend that the Government should undertake an immediate review of the National Literacy Strategy' (Education and Skills Committee, 2005b: 23). The outcome of that review, the Rose Report, devoted four pages to the Clackmannanshire study and recommended that all English children be taught to read using systematic synthetic phonics, taught discretely as the prime approach in learning to read (DfES, 2006). In Scotland, the Clackmannanshire experiment has not been ignored, but has not generated the highly charged debates or radical policy and curriculum overhauls seen south of the border. In contrast to the reaction in England, the Scottish HM Inspectorate of Education (HMIe) report concluded: 'Whilst this programme had made a strong impact on pupils' 
ability to sound out, spell and recognise words, further work was required to link these skills to other aspects of reading such as comprehension’ (HMIe, 2006: 4).

This article does not seek to discredit synthetic phonics or the work in Clackmannanshire. Instead, it explores why Scotland and England responded in such different ways to this study. It argues that differences in the way literacy policy is determined in Scotland, and a greater knowledge of the wider funding and policy context, can explain the more measured response from Scottish policy makers. Further, it argues that consideration of the national and local staff development context provides another story about the study, one that sits alongside the psychology research with its focus on individual performance and teaching programmes. A third story arises from consideration of the national test data for the cohort of pupils in the Clackmannanshire trial. Together, these three stories highlight the complex relationships and tensions between academic research, curriculum development and policy development in literacy.

To do this, the article draws on publicly available sources: HMIe inspection reports, national test results, Clackmannanshire Council Reports and reports on the Learning and Teaching Scotland (LTS) website, which provides national curriculum advice for Scotland. It also draws on evidence from interviews with staff working in Clackmannanshire schools during the intervention period. In this way, the article attempts to explain the national policy context and piece together exactly what the local authority actually did, and describe what some teachers and head teachers felt was important and useful.

\section{The Clackmannanshire study}

Clackmannanshire local authority was formed in1994, when Scottish local government was reorganized into 32 local authorities. It is the smallest local authority in Scotland, managing 3 secondary schools and 19 primary schools, some of which are very small.Twenty-four per cent of its primary pupils in 2004 had a free school meal entitlement (compared to a national average of 21\%) but this varies hugely from 5 per cent to 58 per cent between schools. Across the county therefore, there are pockets of wealth and prosperity and some areas of very significant deprivation (HMIe, 2006).

The Clackmannanshire experiment was carried out by Joyce Watson and Rhona Johnston of St Andrews University. The seven-year longitudinal study, which so impressed the Westminster Select Committee, was one of three linked studies on phonics. The studies addressed the academic debates among psychologists about how young children set about learning the connections between letters and sounds, the knowledge and skills that are needed, the optimum pace and sequence of letters/sounds, and when these 
should be taught. Proponents of analytic phonics (e.g. Goswami, 2005) argue for a developmental sequence in which rhyming skills help children draw analogies between words to crack the alphabetic code. This, they suggest, better suits the irregular 'deep' orthography of English. Others (e.g. Stuart, 2006) argue for synthetic phonics, where the key to cracking the alphabetic code lies in teaching children to recognize and blend (or synthesize) individual letter-sound correspondences as early as possible, avoiding distractions such as rhyme.

The first study took place in 1992-3 (before Clackmannanshire was formed) and was part of the research for a PhD. It is described variously as a study of 'methods of teaching reading and spelling' and 'research examining how phonics was taught' in 12 schools (Watson and Johnston, 1998). This study described the phonics teaching and examined the content, pace and impact of the programmes. It reported serious reading gains as soon as teachers began showing children how to decode CVC words. It also reported that a class following an accelerated analytic phonics programme made greater gains than those on slower phonics programmes. The second study was also designed to address a theoretical issue: '. . whether synthetic phonics was more effective than analytic phonics merely because letter sounds were taught at an accelerated pace' (Johnston and Watson, 2004: 343). It was a 10-week intervention, and the 92 children were tested up to the end of their first year of school.

For 10 weeks, three groups of children were extracted for two 15-minute sessions of extra tuition a week. One group had sight vocabulary training only (i.e. no additional phonics tuition beyond that included in the normal class programme), another was taught two letters a week in an initial position in words (the 'analytic phonics' group) and the third group was also taught two letters a week but in the initial, middle and final position (the 'synthetic phonics' group). Children from four classes were randomly assigned to groups to control for possible effects of different class teachers and reading programmes. Because the lead researcher was also the teacher for the extracted groups, this was not a typical randomized controlled trial. From this study Watson and Johnston concluded that synthetic phonics led to better reading, spelling and phonemic awareness and that the advantage lay in showing children how to sound and blend letter sounds to pronounce unfamiliar words (Watson and Johnston, 1998).

The third study is the one that will be discussed in this article. It created huge media excitement and policy debate in England and further afield (Department for Education and Skills [DfES], 2006; National Inquiry into the Teaching of Literacy [NITL], 2005). Johnston and Watson (2005a) report that it involved around 300 children and was jointly funded by Clackmannanshire Council and the Scottish Executive. It began in 1997-8 and was given additional funding in 1999. This study is important and deserves attention because it is one of very few longitudinal phonics studies 
to follow a cohort of children to the end of their primary career. This cohort study sought to contribute to psychologists' understanding of the reading process by comparing the effects of phonemic awareness, analytic phonics and synthetic phonics instruction on reading and spelling. One hypothesis was that 'if training in phonological awareness is essential for young children learning to read, the analytic phonics programme with phonological awareness training should be more effective than the other two programmes' (Johnston and Watson, 2004).

The first phase of the longitudinal project was a 16-week programme, implemented with 13 classes in 8 schools. Five 'synthetic phonics' classes did 20 minutes of whole-class synthetic phonics per day.They were taught six letter sounds in eight days in initial, middle and final positions, together with the formation of the letters. They were taught to sound and blend letters and were shown how to use this to both read and spell words. Four 'phonemic awareness/analytic phonics' classes did 10 minutes a day of phonemic awareness training without reference to print and a separate 10 minutes of analytic phonics, covering just 1 sound per week. A control 'analytic phonics' group of 4 classes did 20 minutes a day of analytic phonics, also covering 1 sound per week.The class teachers did all teaching. After 16 weeks, tests on word reading showed the analytic and phoneme awareness/analytic groups were reading one month behind their chronological age. The synthetic phonics group were seven months ahead of their chronological age, and seven months ahead of the other two groups. In spelling, the synthetic phonics group was eight months ahead of the analytic phonics group and nine months ahead of the analytic phonics/phoneme awareness group. Watson and Johnston (1998: 7-8) concluded that synthetic phonics was a more effective teaching method than analytic phonics.

In the second phase, those classes initially not given synthetic phonics followed the synthetic phonics programme, completing it by the end of their first year at school.Towards the end of their second year, all 13 classes were re-tested. The reading and spelling averages for all groups were well above their chronological age and there was no significant difference in word reading or comprehension between the three original groups, although there was a significant difference in favour of the original synthetic phonics group for spelling.

This cohort was followed through to the end of their primary school career. The report on this seven-year longitudinal study was summarized and published by the Scottish Executive (Johnston and Watson, 2005a).The children were, on average, three years and six months ahead of chronological age in decoding words.They were one year and nine months ahead in spelling and were three and a half months above the expected level for their chronological age in comprehension. The report concluded that 
synthetic phonics was a highly effective teaching method that produced long-lasting effects.

The full research report was published on the Scottish Executive Education Department's (SEED) website (Johnston and Watson, 2005b). This gave more detail about the study (although not an abstract, a timeline or a participant flow diagram, all of which would have been helpful). This detailed some aspects less central to the synthetic/analytic phonics debate; for example, boys had less positive attitudes towards reading than girls. The longitudinal study had huge press coverage in both Scotland and England, mostly focused on the three and a half year gain in decoding single words.

\section{The national context in Scotland}

One key to understanding Scotland's very different reaction to the Clackmannanshire study lies in the way that Scottish education policy is organized and developed. In Scotland, there is no central, legally enforced national curriculum. Instead, there are non-statutory curriculum guidelines and the Minister in charge of education is legally required to set National Priorities for education, and to review these from time to time. The National Priorities are few (there are currently five) and fairly broad. For example, one current priority is: 'To raise standards of educational attainment for all in schools, especially in the core skills of literacy and numeracy, and to achieve better results in national measures of achievement, including examination results' (SEED, 2007: 1). Performance outcomes and measures sit alongside each priority to provide a common measure for standards and quality. Each local authority is expected to interpret and deliver the curriculum guidelines and National Priorities in a way that meets local needs. The Director of Education for each local authority must present and explain the authority's literacy policy to local councillors and use the performance measures and other nationally agreed performance indicators to evaluate how effectively it is working.

This devolved decision-making has two effects. First, it removes the literacy curriculum (although not literacy itself) from national political debate. This means that parliamentary politicians, who have excellent understandings of how to deliver soundbites and capture media attention, but often know less about literacy teaching or interpreting statistical evidence, cannot make political capital by aligning themselves with a particular teaching approach; they simply have no locus in such decisions. Directors of Education, answerable to locally elected councillors and working to agreed and common evaluation and performance structures determine how the literacy guidelines are interpreted and delivered. Whereas in England the Conservative MP, Nick Gibb, could use parliamentary 
questions about Clackmannanshire to challenge Labour's education policy, in Scotland he would have met the standard Scottish Executive response: 'We do not have a statutory curriculum in Scotland, so we do not prescribe to local authorities how they have to teach a particular subject' (Andalo, 2005: 3).

Second, devolved decision-making locates discussion about the literacy curriculum firmly in the hands of those who have to deliver it. This results in a more measured and nuanced professional debate about literacy teaching and literacy learning. It also fosters appreciation of the hard work, commitment and imagination that underpins any successful curriculum innovation. Wholesale dismissal of the Clackmannanshire study would be regarded as both discourteous and unwise. Rather, the reaction of teachers and policy makers at local authority level has been to see what lessons might be learned and ideas adapted and applied to their own, parallel innovations. This process of curriculum development by 'evolution rather than revolution' (Humes and Bryce, 2003) is highly pragmatic, driven by 'what works in this context' rather than by theoretical constructs. It is an approach that contrasts strongly with the concerns with 'programme fidelity' expressed in the Rose Review.

Moss and Huxford (2007), in their analysis of the phonics debate in England, maintain that 'Phonics in the policy context is not the same as phonics in the research context or phonics as a focus for a political campaign'. Each interprets the question of how to raise literacy achievement in a different way, works to different timelines and recognizes different evidence. In each context, what phonics 'stands for' varies, and is differently positioned in relation to the various tiers at which national policy decisions are made and interpreted. The devolved and evolutionary approach to literacy policy in Scotland possibly curtails the number of different things phonics can 'stand for' and aligns it more closely to learning, in a smaller, more localized policy space. This may explain why there are fewer struggles around it.

\section{The national funding context for The Longitudinal Clackmannanshire Study}

Although decisions about the curriculum are devolved, the Scottish Executive uses ring-fenced funding to encourage local authorities and schools to attend to particular issues. In 1997, £20m was made available nationally on a matched-funds basis, for early intervention initiatives to raise literacy and numeracy attainment in the first two years of school. For a country the size of Scotland (population 5,102,400) this represents a large amount of money, tightly targeted on the early years school curriculum. All 32 local authorities submitted bids for specific projects. The bids 
were assessed by HMIe and those that addressed too narrow an aspect of literacy were advised to widen their focus and address a number of strands. In 1998, Helen Liddell, then Minister for Education, used the Excellence Fund to extend the funding to $£ 60 \mathrm{~m}$ over 5 years. This enabled local authorities to support further curriculum change as children moved into their third year of school and to 'roll out' the most successful initiatives to other schools.

This then, was the funding context for the longitudinal Clackmannanshire phonics study: it was one part of a broader literacy development project that was specifically designed to raise the attainment of the children during the first three years of school. It took place within a big national project and was funded by money that was additional to the local authority’s normal education budget.

The first year of Clackmannanshire's project involved the eight intervention schools in two main initiatives. One was the synthetic phonics study and the other introduced new core reading schemes and library books into the schools (Robertson, 2005). After the first year, the local authority was keen that the pupils in the experimental phonics cohort built on their knowledge and skills during their second year of primary education. They used the early intervention money to develop a Primary 2 literacy programme that focused more heavily on developing thinking and comprehension skills. This new programme entailed a new evaluation. Lesley Robertson, the local authority advisor responsible for the project reported to the Clackmannanshire Learning and Leisure Committee of 27 October 1999: 'It was agreed with the University of St Andrews to construct another research programme whereby the progress of pupils in P2 classes involved in the second phase of the programme could be evaluated with the same academic rigour as in the first phase. In broad terms this approach meant that the children continued to build on their basic reading and spelling skills while at the same time, a large part of the teaching programme could Figure 1: Reading Attainment in P7 (\% pupils Level D or above)

\begin{tabular}{|l|l|l|l|l|l|}
\hline & Roll & \% Free & Year: & $\begin{array}{l}\text { Year: } \\
\text { 2003/04 } \\
\text { School } \\
\text { Meal } \\
\text { (intervention } \\
\text { Entitlement } \\
\text { cohort) }\end{array}$ & $\begin{array}{l}\text { Year: } \\
\text { 2004/05 }\end{array}$ \\
& & in 2003/04 & & & \\
\hline A & 488 & 14 & 69 & 70 & 82 \\
\hline B & 409 & 22 & 80 & 84 & 79 \\
\hline
\end{tabular}




\begin{tabular}{|l|l|l|l|l|l|}
\hline C & 229 & 56 & 47 & 78 & n/a \\
\hline D & 155 & 76 & 47 & 73 & 66 \\
\hline E & 146 & 41 & 57 & 44 & 72 \\
\hline F & 114 & 45 & 44 & 20 & 21 \\
\hline G & 63 & 33 & 70 & 91 & 75 \\
\hline H & 277 & 17 & 87 & 77 & 77 \\
\hline
\end{tabular}

National average for P7 pupils at Level D or above in 2003/04 $=74.5 \%$

National average for Free School Meal entitlement in 2003/04 = 21\%

be focused on the acquisition of thinking and comprehension skills. The teaching programme began in September 1998 and the evaluation exercise was carried out in 1999’ (Robertson, 1999: 2).

Clackmannanshire also used the early intervention funding to provide home-school liaison teachers in four of the intervention schools. These teachers provided classroom support for children; made home visits to support literacy development outside school and established story clubs, library visits, after-school homework clubs and parent groups. They also created libraries and borrowing services in the schools (Clackmannanshire Council, 2003).

At national level, there was considerable interchange of ideas across Scotland.Every local authoritywas running its own intervention projects and HMIe organized a national event for coordinators, head teachers and teachers to encourage professional networks and promote cross-fertilization of ideas. Local authorities organized further individual and joint conferences for staff and the national evaluation team set up two opportunities for sharing initiatives and classroom practice (Fraser et al., 2001).

\section{The staff development context}

It is quite clear that at no point did the local authority just give the schools a phonics scheme and tell them to get on with it.The curriculum development process was sensitive to the local context and ensured that those responsible for implementation were intellectually engaged and committed. The teachers developed the deep and grounded understanding that we know is essential for effective and responsive teaching (Blackmore, 1998).The staff development provided in conjunction with the researchers from St Andrews University was systematic, coherent and delivered with conviction. It provided specific content knowledge about phonics and teaching literacy as well as offering practical advice about structuring 
lessons, using the resources, making learning purposeful, motivating children and the importance of noticing and building on success. Teachers discussed how to plan and deliver phonics and literacy lessons that were focused and interactive, with clear learning purposes, explicit links to previous learning and opportunities for children to apply their knowledge and to reflect on what had been learnt.

The Clackmannanshire staff I interviewed were highly enthusiastic about the training they had been given. One head teacher explained:

The professional development they provided really shifted the culture and expectations. I had good, experienced staff working in my school but the previous (professional development) programmes had all offered a straight choice between pottery and computing . . . everything was a 'how to' course. Before, there'd been nothing on core curriculum subjects like literacy, and nothing to engage the brain.

The teachers particularly liked the clear focus on just one new aspect of content knowledge: one teacher told me 'it [the course] was . . very clear. You just had one single thing to master. They didn’t suggest loads of different ideas so that you had to divide your attention when you went back, or have to work out what should be your main priority'. Another said, 'The CPD gave you wonderful confidence.They said "just do this and do it really well”. Because we were all doing the same thing ... [we] . . all had common problems and could support each other'.

Although all the teachers I spoke to spent longer than the 20 minutes originally suggested as the length of a phonics lesson - some (e.g. Macnair, 2006) reported lessons lasting as long as an hour - all appreciated the clear and practical advice about lesson delivery, the pace of teaching and the importance of providing opportunities for pupils to practise and apply their learning. Writing in The Scotsman, Lesley Robertson, the staff tutor for Clackmannanshire's early intervention and phonics initiative, says, 'In attempting to define the success of the programme,we believe that a significant component of the methodology is the explicit modelling of the thinking process by the teacher' (Robertson, 2005: 4).

When school reforms fail, the head teacher is often to be seen supporting the reform from a distance, rather than directly leading it (Datnow et al., 2002). In Clackmannanshire, the new approaches were explained in detail to the head teachers and senior management teams before they were explained to the teachers. This ensured commitment and informed support from these crucial managers. One teacher said, 'Follow-through in school was fantastic. My head teacher was really interested and enthusiastic. The expectations were high, but I had clear targets, with encouragement and support to get there'.

The teachers involved in the first few project cohorts were clearly excited 
about being at the cutting edge of research and felt empowered to actively shape the project and suggest ways to develop the materials to better support children's learning. For example, the teachers suggested introducing physical movement into lessons to allow children to release some energy and reduce frustrations arising from the amount of time spent sitting still. The report to councillors on Clackmannanshire's Learning and Leisure Committee acknowledges this: 'The Scottish Office had indicated an interest in contracting with the University of St Andrews to produce a CD Rom containing the materials [that were] developed in conjunction with teachers in Clackmannanshire’' (Robertson, 1999: 1).

Alongside the phonics programme was a rigorous system for monitoring the progress of individual pupils and providing support to those who needed it with catch-up groups and homework clubs for anyone who seemed to be falling behind. Johnston and Watson (2005b) point out that none of the children in the original synthetic phonics group required additional support, but that some who had originally been part of the other two groups did require this support. The head teachers and some teachers I interviewed were strongly in favour of the additional support system. One experienced class teacher was less enthusiastic; she felt that children who struggled in the phonics lessons might experience more enjoyment and easy success in PE or Art but were taken out to do more phonics. This, she felt created an early, negative experience of school.

The system, from the time it was first set up, also monitored and supported the staff. Lesley Robertson, the local authority advisor was a talented administrator but was also dedicated and knowledgeable about teaching phonics and literacy. She worked closely with the researchers and the teachers and had huge credibility with the head teachers and senior management staff in schools. One head teacher said, 'It was great to have someone on the end of a phone who you could ring up with any questions - even questions about an individual child, and you knew you could have a sensible discussion with someone who was knowledgeable and could give you good advice about what to try'.

The decision to focus on one cohort of pupils and introduce new resources, study programmes and Continuing Professional Development (CPD) to the teachers as this cohort moved into their class ensured that teachers got a clear message of what was expected, that the CPD was provided at the point of need and that school managers knew what they should expect to see happening in class. Other early intervention projects in Scotland provided CPD to the Primary 1 and Primary 2 teachers together. This meant that the Primary 2 teachers had to adapt the new ideas for a cohort of pupils who had received no intervention programme before trying it properly with the intervention cohort a year later. In effect, they had a year to forget what they had been told. In the Clackmannanshire 
model, the Primary 2 teachers were given the relevant CPD only when the intervention cohort arrived as their class. Everyone accepted that this cohort of pupils was bringing a different set of knowledge and skills and the Primary 1 teachers were keen to offer focused support and advice.This itself created an internal pressure: a Primary 2 teacher reported embracing the initiative mainly because her Primary 1 colleague was so interested to see how she was building on the children's previous work.

A rolling programme of courses about teaching literacy and phonics was established to 'catch' teachers transferred to Primary 1 or Primary 2 classes halfway though the year. If no courses were running in the first four to six weeks of taking over a class, the new teacher was sent to other schools to observe how that stage was taught. One head teacher told me: 'The whole thing was organised and managed so that no-one in the system was left unsupported'.

Clackmannanshire was not the only local authority to introduce synthetic phonics as part of its early intervention strategy. Others also tried, but with less success, which alone makes Clackmannanshire worthy of attention.This was undoubtedly a well-designed intervention and the design features fit with a lot of what we now know about successful staff development and curriculum reform: it had an authentic beginning and systematically built ideological commitment in the key staff. It was understood as a long-term initiative rather than a short-term 'cure', was supported by policy development at all levels and had internal feedback loops to monitor and support progress (Datnow et al., 2002).

\section{The different contexts and aims of policy and research}

Rhona Johnston (2006) has argued that none of this additional information about staff development and other initiatives can explain the advanced phonic decoding skills that the Primary 7 cohort displayed - on average three and a half years ahead of their chronological age. She is quite right, which makes this a valuable and interesting result for those who study the psychology of reading. However, it also illustrates one of the tensions that can arise from using tightly focused psychology research to inform policy development. The researchers and policy makers are driven by different questions and recognize different evidence as legitimate. For parents and policy makers, there is no practical advantage to children being able to sound out complex individual words as an isolated skill. The pragmatic policy task is to design and implement a literacy curriculum that creates readers who are significantly better at reading for meaning; people who can visualize as they read, infer meaning, recognize key ideas, new knowledge and contradictions and who are able to use and apply what they read to real life situations. 
Pawson (2005) suggests that different perspectives value different kinds of questions and different kinds of evidence. The tightly focused questions that drive academic research can be problematic for policy makers who must attend to contextual features and evidence that researchers often consider unreliable, irrelevant background information or simply 'noise' to be screened out. He suggests that instead of focusing on single programmes and asking 'what does and doesn't work', policy makers should embrace complexity by asking 'what works, for whom and in what circumstances' (Pawson, 2005).

'What works' for psychology researchers working in a tightly delineated and relatively slow-moving domain of phonics research may not work for policy makers, teachers or curriculum developers, who must work to different timescales and across a range of contexts and forms of evidence (Moss and Huxford, 2007). For example, one source of evidence that policy makers use about 'what works' is national test results. In Scotland, children sit a national test in reading or writing when the teacher judges them to have attained a 5-14 Level. This means that small groups of children, or even individuals, will be sitting tests at different points throughout the year. The system is set up to reflect what children can currently do, rather what they could do at some arbitrary point decided by a national exam board. Moreover, it is biased in favour of the child and teacher judgement; if a child does badly in the test but the teacher has robust evidence from classroom work that the child has attained the level, they can award it.

For experimental psychologists, the Scottish 5-14 national test items are imperfect: they not standardized, they are administered by the classroom teacher and are not externally marked.Yet from a policy maker's perspective they are valuable because they reflect real-life literacy expectations and mirror the literacy demands of normal classroom practice, which is rarely true of psychology tests.

In Scotland, national testing is not compulsory, but national test results are used by many local authorities, including Clackmannanshire, as part of their internal monitoring and evaluation procedures. Local authorities monitor when children attain each level and are told how their own results rank against comparator local authorities. HMIe also comment on test results when they inspect local authorities and schools. For example, the HMIe (2006) inspection report on Clackmannanshire reports that, in Primary schools, the 'performance in all three areas (reading, writing and mathematics) was below the average for comparator authorities and national averages' (HMIe, 2006: 4).

The official expectation is that most children will have attained Level D by Primary 7, the last year of primary school. In practice, this yardstick is 
rather long; the percentage of children attaining levels early has steadily increased since the system was introduced and most local authorities expect many (but not all) children to have achieved Level D by the end of Primary 6.

The national test results are shared with children and parents but the government does not centrally collect them, or publish 'league tables' of schools or local authorities. In 2005, however, The Sunday Times (Scotland) used the Freedom of Information Act to request the Primary 7 national test results for every school and local authority in Scotland (Fracassini et al., 2005).Table 1 summarizes the Primary 7 national test results for the eight schools involved in the early intervention study. It details the percentage of children in Primary 7 awarded Level D for the year before the research cohort, the research cohort and the year after the cohort.

The percentage of Free School Meal (FSM) entitlement is a broad indicator of the socio-economic status of families in the school. Literacy attainment is linked to this and, in Scotland, pupils in the bottom quarter of the socio-economic index are more than twice as likely to be among the bottom 25 per cent for reading attainment (SEED, 2002). The school roll indicates the size of the school. It is the total number of children attending the school and can only hint at the number of children in a particular year-group. Reporting results in terms of pupil percentages is always problematic: in small schools with small year-groups, the under- or overperformance of just one or two children can create a relatively large percentage 'swing' from year to year. The percentage results for bigger schools are more robust.

Obviously, firm conclusions cannot be drawn from this data. However, it does raise some questions for policy makers. Despite all schools getting a synthetic phonics input, there appears to be variability in national test achievement between the eight schools in the study. This does not, as one

Table 1 Reading attainment in P7 (\% pupils Level D or above)

\begin{tabular}{|l|l|l|l|l|l|}
\hline & Roll & $\begin{array}{l}\text { \% Free } \\
\text { School } \\
\text { Meal } \\
\text { Entitlement } \\
\text { in 2003/04 }\end{array}$ & $\begin{array}{l}\text { Year: } \\
\text { 2002/03 }\end{array}$ & $\begin{array}{l}\text { Year: } \\
\text { 2003/04 } \\
\text { (intervention } \\
\text { cohort) }\end{array}$ & $\begin{array}{l}\text { Year: } \\
\text { 2004/05 }\end{array}$ \\
\hline A & 488 & 14 & 69 & 70 & 82 \\
\hline B & 409 & 22 & 80 & 84 & 79 \\
\hline C & 229 & 56 & 47 & 78 & n/a \\
\hline D & 155 & 76 & 47 & 73 & 66 \\
\hline E & 146 & 41 & 57 & 44 & 72 \\
\hline F & 114 & 45 & 44 & 20 & 21 \\
\hline G & 63 & 33 & 70 & 91 & 75 \\
\hline
\end{tabular}




\begin{tabular}{|l|l|l|l|l|l|}
\hline $\mathrm{H}$ & 277 & 17 & 87 & 77 & 77 \\
\hline
\end{tabular}

Notes: National average for P7 pupils at Level D or above in 2003/04 $=74.5 \%$

National average for Free School Meal entitlement in 2003/04 = 21\%

might expect, reflect the FSM entitlement. Some of the schools are doing very well indeed: Schools C, D and G, in 2003-4 had FSM entitlements way above the national average, 56 per cent, 76 per cent and 33 per cent respectively, yet are attaining, and in two cases exceeding, national averages completely stunning results. Others, schools E and F for example, with similar catchments, are doing less well.

The largest school in the cohort, School A, serves the most advantaged catchment area with a FSM entitlement of 14 per cent, well below the national average. Yet its results are only in line with national attainment. Even 82 per cent attainment in the following year (2004-5) is disappointing. Schools with similar catchments in local authorities such as East Renfrewshire were at this time regularly attaining in the region of 90 per cent plus.

There are two points that emerge from this brief analysis. First, it seems there may be patterns of school-level variation that could be interesting and important for policy makers but are not made apparent by a psychology research paradigm that focuses on individual achievement scores and programmes of study.

Second, the national test results should not be seen as a direct challenge to the raft of standardized test results reported for the Clackmannanshire study. The psychology tests and national tests have emerged from different paradigms and measure different things. This analysis merely shows that one cohort's reading achievement can look quite different under different lenses. A potential problem for policy makers and teachers in England is that the lens used by the Westminster government to measure success in reading bears more similarity to the Scottish 5-14 tests than to the raft of reading tests used by the Clackmannanshire researchers.

Moss and Huxford (2007) argue that literacy problems are not couched within a single paradigm's field of reference. Perhaps the real lesson from this broader examination of the Clackmannanshire study is that any study driven mainly by one paradigm can only offer limited insights. Other Scottish local authorities deliberately created multi-paradigm projects in response to the national early intervention initiative.West Dunbartonshire, serving the second poorest area in Scotland (Clackmannanshire, as the eighth poorest area, is slightly better-off), designed possibly the most successful intervention and based it on a 'literacy for all' agenda.The starting 
point was that curriculum change is about contexts and staff as well as programmes and teaching content, 'Civil servants working under the directives of politicians don't bring about inspiration and revolution, and revolution is what is needed if you're going to turn things right around' (MacKay cited in Smith, 2007).The West Dunbartonshire intervention was

not driven by a desire to know which theory works the best, but by the need to address a raft of complex, real-world literacy issues. Phonics is an important part of the early literacy programme but teachers draw on both analytic and synthetic approaches. The Hanen (2002) programme is also used to train staff to support and promote children's language and communication and there is an important emphasis on noticing and celebrating literacy achievement (Mackay, 2006).

Moss and Huxford (2007) argue that different groups within the phonics community in England have increasingly manoeuvred to control the policy space around early literacy. It is important that academics and policy makers continue to respect the insights afforded by a multi-disciplinary approach to literacy policy, even when some aspects of the system do not naturally promote such a view. One of the psychologists on the Rose Review famously told the Westminster Select Committee of Enquiry into Reading, 'The research on reading goes on in psychology departments'. The Chairman asked, 'So we should listen to psychologists more than educational researchers?' and she replied, 'Yes' (Education and Skills, 2005a:5, Q. 38-9). The evidence in this article suggests that the Select Committee and those who produced the Rose Review might have been well advised to ignore her reply and listen to both. This, it seems, is what policy makers in Scotland have chosen to do.

\section{References}

Andalo, D. (2005) 'Reading Scheme will not be Rolled Out in Scotland', Guardian (3) June): 3, URL: http://education.guardian.co.uk/schools/story/0,,1498836,00.html.

Blackmore, J. (1998) 'The Politics of Gender and Educational Change', in A. Hargreaves, A. Liberman, M. Fullen and D. Hopkins (eds) International Handbook of Educational Change, pp. 460-81. Norwell, MA: Kluwer Academic.

Clackmannanshire Council (2003) My Mum Likes School: Evaluation of the Effectiveness of HomeSchool Liaison Work in Increasing Parental Involvement in Four Core Schools. Clackmannan: Clacks Council Early Learning Initiatives.

Datnow, A., Hubbard, L. and Mehan, H. (2002) Extending Educational Reform: From One School to Many. London: RoutledgeFalmer.

Department for Education and Skills (DfES) (2006) Independent Review of the Teaching of Early Reading: Final Report, 'The Rose Review'. London: DfES.

Education and Skills Committee (2005a) Eighth Report:Witnesses Monday 15 November 2004: Dr.Morag Stuart. London: United Kingdom Parliament, URL (consulted 16 May 2005): 
http://www.parliament.the-stationery-office.co.uk/pa/cm200405/cmselect/cmeduski/ 121/12111.htm Education and Skills Committee (2005b) Teaching Children to Read: Eighth Report of Session2004-5. London: HMSO.

Fracassini, C., Farquharson, K. and Marney, H. (2005) 'Focus: Secrecy that Fails Scotland(Or What the Executive, Unions, Councils - and Even Some Parents Don't WantYou To Know)', Sunday Times (Scotland) (13 November), URL (March 2006): http://www.timesonline.co.uk/article/0,2090-1870190_1.00html

Fraser, H., MacDougall, A., Pirrie, A. and Croxford, L. (2001) 'Early Intervention in Literacy and Numeracy: Key Issues From the National Evaluation of the Programme', Interchange 71. Edinburgh: SEED.

Goswami, U. (2005) 'Synthetic Phonics and Learning to Read: A Cross-Language Perspective', Educational Psychology in Practice 21(4): 273-82.

Hanen (2002) Learning Language and Loving it: A Guide to Promoting Children's Social, Language, and

Literacy Development in Early Childhood Settings (Second Edition). Canada: Weitzman and Greenberg. HM Inspectorate of Education (HMIe) (2006) 'Pilot Inspection of the Education Functions of Clackmannanshire Council in October 2005', SEED, Edinburgh, http://www.hmie.gov.uk/documents/inspection/ClackmannanINEA2Pilot.html

Humes,W.M. and Bryce, T.G.K. (2003) 'The Distinctiveness of Scottish Education', in T.G.K. Bryce and W.M. Humes (eds) Scottish Education: Second Edition PostDevolution, pp. 108-18. Edinburgh: Edinburgh University Press.

Johnston, R.J. and Watson, J.E. (2004) 'Accelerating the Development of Reading, Spelling and Phonemic Awareness Skills in Initial Readers', Reading and Writing 17: 327-57.

Johnston, R. and Watson, J. (2005a) 'A Seven Year Study of the Effects of Synthetic Phonics Teaching on Reading and Spelling Attainment', Insight 17. Edinburgh: SEED.

Johnston, R. and Watson J. (2005b) The Effects of Synthetic Phonics Teaching on Reading and Spelling Attainment: A Seven Year Longitudinal Study. Edinburgh: SEED.

Johnston, R. (2006) Personal Communication, 8 April 2006.

MacKay,T. (2006) The West Dunbartonshire Literacy Initiative:The Design, Implementation and Evaluation of an Intervention Strategy to Raise Achievement and Eradicate Illiteracy - Phase I Research Report. Dumbarton:West Dunbartonshire Council.

Macnair, L. (2006) 'Inside the Classroom: Three Approaches to Phonics Teaching (Synthetic Phonics - How I Teach It)', in M. Lewis and S. Ellis (eds) Phonics: Practice, Research and Policy, pp. 45-59. London: Sage.

Moss, G. and Huxford, L. (2007) 'Exploring Literacy Policy-Making From the Inside Out', in L. Saunders (ed.) Exploring the Relationship between Educational Research and Education Policy-Making. London: RoutledgeFalmer.

National Inquiry into the Teaching of Literacy (NITL) (2005) Teaching Reading: Literature Review. Melbourne: Australian Government, Department of Education, Science and Training.

Pawson, R. (2005) Evidence-based Policy: A Realist Perspective. London: Sage. 
Robertson, L. (1999) Report to Learning and Leisure Committee of 27 October 1999, Clackmannanshire Early Learning Initiative: Third Progress Report. Clackmannan: Clackmannanshire Council, URL (consulted March 2006): http://72.14.203.104/search?q=cache:jHEYgXxY578J:Itscotland.org.uk/images/cl aloceval1_tcm4-122377.pdf

Robertson, L. (2005) 'Why Synthetic Phonics was a Natural Winner', Scotsman (27 April), URL (consulted March 2006): http://thescotsman.scotsman.com/ education.cfm

Scottish Executive Education Department (SEED) (2002) Programme for International Student Assessment: Scottish Report, Education and Young People Research Unit. Edinburgh: SEED. journal of early childhood literacy 7(3) 296281-297 083660 Ellis (D) 3/9/07 13:37 Page 296

Scottish Executive Education Department (SEED) (2007) National Priorities for Education. Edinburgh: SEED, URL (consulted March 2007): http://www.nationalpriorities.org.uk/schools/priority1.html

Smith, C. (2007) ‘One Man’s Quest to Eradicate Illiteracy’, Independent (8 March), URL(consulted March 2007): http://education.independent.co.uk/careers_advice/article2336440.ece

Stuart, M. (2006) 'Teaching Reading: Why Start With Systematic Phonics Teaching?', The Psychology of Education Review 30(2): 6-17.

Watson, J.E. and Johnston, R.S. (1998) 'Accelerating Reading Attainment: The Effectiveness of Synthetic Phonics’, Interchange 57. Edinburgh: SEED. 